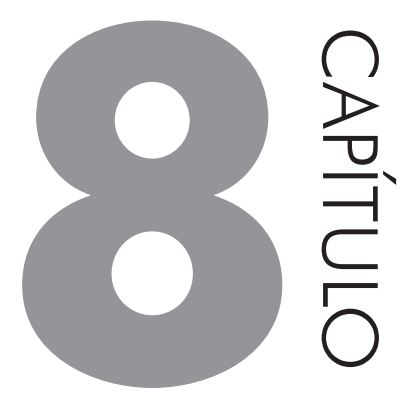

\title{
A TUTORIA, O PIONEIRISMO E A MATEMÁTICA
}

\section{JOSÉLIO CARLOS DE OLIVEIRA}

\section{APRESENTAÇÃO DA TUTOR}

Sou Joselio, Tutor presencial no Polo Recife, do curso de Matemática, Modalidade à Distância pela UFPE/UAB. Meu ingresso para a tutoria se deu através de prova escrita e análise de currículo em 2010, onde demos início à primeira turma do curso no Polo Recife, que funcionava em um dos prédios do antigo colégio Nobrega, no então CETEC- Centro de Educação e Tecnologia, ligado à Secretaria de Educação do Recife, na rua Oliveira Lima, na Boa vista. Hoje, o Polo Recife funciona na Escola de Formação e Aperfeiçoamento de Educadores do Recife (EFAER), na Madalena.

Minha formação educacional foi realizada em escolas públicas estaduais, no turno da noite, pela necessidade de trabalhar durante o dia, desde os meus 14 anos de idade, para ajudar meus pais a alimentar as dez pessoas da família. Conclui o ensino médio na Escola Técnica Estadual Professor Agamenon Magalhães (ETEPAM), no curso de Mecânica. Após várias tentativas frustradas na época do vestibular Unificado, para cursar engenharia mecânica, resolvi fazer o vestibular da FUNESO, onde conclui o curso de Ciências com Licenciatura em Matemática.

Em 1987, passei no concurso para professor da Secretaria Municipal de Educação da Prefeitura do Recife, nesse período lecionei em várias Escolas na perife- 
ria da cidade, contribuindo também como gestor escolar e em formação de professores da rede. Buscando o aperfeiçoamento profissional, concluir dois cursos de especialização, um de Expressão Gráfica pela UFPE e outro de Informática Educacional na Faculdade Frassinette do Recife (FAFIRE).

\section{SÍNTESE DO PERCURSO NA TUTORIA}

A partir do meu ingresso no quadro de Tutores do Curso de Matemática Modalidade à Distância (UFPE), recebemos os estudantes com uma apresentação da proposta curricular, carga horária e normas de funcionamento, em conjunto com o Professor Miguel, coordenado do curso. O prédio não tinha muita estrutura, com duas salas disponíveis, quadro e ventiladores nas paredes. Essa falta de estrutura nos levou a reivindicar a mudança do Polo para outro local. Foi quando conseguimos mudar para a Escola de Formação e Aperfeiçoamento de Educadores do Recife (EFAER), na Madalena. Nesse local formamos a primeira turma do Curso de Matemática. Uma turma que iniciou com cerca de cem estudantes, tendo em 2014, os dez primeiros formados do primeiro curso em EaD ofertado pela UFPE.

Essa turma de desbravadores, apesar de muito unida e crítica, cobrava bastante os encontros presenciais, tanto com os tutores, como com os próprios professores. Várias vezes o professor Miguel, Willian e Marcus Vinícius vieram ao Polo, atendendo aos pedidos dos alunos.

\section{FATO MARCANTE NA TUTORIA}

A primeira turma do Curso de Matemática, modalidade à Distância, pela UFPE/UAB no Polo Recife, teve uma característica: a diversidade dos estudantes. Foi constatado alguns alunos que já haviam parado de estudar há mais de dez anos. Um exemplo, foi uma aluna que era uma dona de casa, que só queria ter uma formação acadêmica para se equiparar à formação do marido. Outros que já lecionavam em escolas particulares da comunidade, há anos, com a formação de ensino médio, e outros que tinham o sonho em ser aprovado em um concurso para lecionar em escolas públicas.

Marcante mesmo foi presenciar os esforços de pessoas humildes, que tiveram a oportunidade de ingressar em um curso ofertado pela melhor Universidade do Estado de Pernambuco, a maioria com uma base de formação deficiente para um curso tão importante e 'difícil'. Era uma turma que tanto cobrava dos professores, Tutores e coordenação, como marcava encontros para estudar e também para o lazer. 
Foi fascinante ver a empolgação da estudante 'Maria da Conceição' ao se tornar representante da turma, assim como vê-la provocar os colegas para contribuírem para a poupança, no intuito de pagar as despesas da colação de grau e do baile, realizado na Casa Rosada, no bairro do Espinheiro.

A maior alegria é saber que o Curso ao qual sou Tutor obteve a nota máxima na avaliação do MEC, e que teve o Estudante Everton, laureado em 2016.

\section{MÉTODO POTENTE UTILIZADO NO PROCESSO DE ENSINO-APRENDIZAGEM}

Nos meus primeiros anos de estudo, aprendi de forma muito diferente dos dias atuais. Era uma época onde parecia que o mundo estava sendo 'formado'. A professora me entregava uma tarjeta com o meu nome para que eu copiasse todos os dias, na sala de aula, o alfabeto e a tabuada. Já no ensino fundamental, como estudava à noite, porque trabalha durante o dia, mal conseguia absorver os conteúdos das disciplinas de Língua Portuguesa e Matemática, que eram menos de memorização, do que as das disciplinas de História e Geografia, por exemplo.

No curso de EaD, em especial, ao qual exerço o papel de tutor, podemos observar que cada vez mais as pessoas precisam aprender com as outras e com as experiências já incorporadas de outras aprendizagens. Para fazer um curso em $\mathrm{EaD}$, o estudante precisa de disciplina, organização de tempo e principalmente do domínio das ferramentas da tecnologia. Uma das primeiras dificuldades apresentadas pelos estudantes foi se livrar da dependência da presença física do professor, depois, dominar e usar as ferramentas do ambiente virtual de aprendizagem. Era estritamente necessário que os alunos conhecessem todo o ambiente virtual, uma vez que todas as tarefas eram realizadas lá, desde as administrativas, como a matrícula, escolha das disciplinas a cursar, como para ver as notas no SIG@.

Percebi neste curso as tecnologias da informação e comunicação atuando como ferramentas mediadoras e facilitadoras do processo de aprendizagem. Aos poucos, cada estudante buscava organizar e adequar seus estudos, quer seja buscando outras maneiras de resolução de problemas através de vídeos no Youtube, ou através dos encontros presenciais em pequenos grupos. Porém, o método mais eficaz, foi sempre mediação do Tutor, na medida em que era procurado pelos estudantes, orientando-os no uso do aplicativo Latex, e estimulando sempre a pesquisar para a resolução de problemas das diversas disciplinas.

\section{LIMITAÇÕES NO PROCESSO DE TUTORIA}

No ensino da modalidade EaD, o papel do Tutor é de suma importância para os estudantes, uma vez que ao prestar todo o apoio no processo de aprendizagem, 
os Tutores estão contribuindo diretamente para a melhoria dos processos pedagógicos, na perspectiva de facilitar a forma como os alunos irão aprender os conteúdos dos cursos aos quais estão matriculados.

Enquanto Tutor, desempenho o papel de atuar como impulsionador para àqueles estudantes desmotivados, tendo consciência de que esta atitude, é de suma importância para o bom desempenho dos que buscam atingir seus objetivos. Sabendo que por outro lado, a falta de atenção por parte dos Tutores e professores pode ser o motivo de evasão dos estudantes, percebo ser esta uma das maiores dificuldades nesse processo. Outro ponto, é que o Tutor não tem a oportunidade de planejar os conteúdos junto ao professor da cadeira e nem de discutir as pendências apontadas pelos próprios estudantes.

\section{PERSPECTIVA DA TUTORIA COMO PROJETO EDUCACIONAL}

É necessário que todos os envolvidos realizem uma reflexão sobre o que é ser professor-Tutor, contextualizando sua importância na educação a distância nos momentos online e offline, ressaltando as diferenças que podem existir entre suas atividades e as do professor convencional. Para isso é preciso discutir as barreiras enfrentadas nesse meio, bem como as estratégias para vencer a distância de espaço e tempo, existentes entre o professor e o estudante. Há que se buscar soluções para entender se os Tutores realizam realmente o papel de ensinar e, principalmente, a importância da função dos Tutores nos cursos a distância online.

O mundo está cada vez mais focando em torno da tecnologia e 'não tem mais volta'. Sabe-se que as pessoas já estão saindo do papel de simples usuários para programadores. Dessa forma, entendo que a tendência é cada vez mais o surgimento de escolas abertas online, onde os estudantes serão protagonistas de sua própria aprendizagem, sendo a Tutoria o pontapé inicial para consolidação desse novo paradigma. 